\title{
A Structural Equation Modeling on Relationship between Self-Efficacy, Physics Laboratory Anxiety and Attitudes
}

\author{
Namudar İzzet Kurbanoğlu $\quad$ Mithat Takunyacı ${ }^{2}$
}

\begin{abstract}
The success of the students in the physics lab depends on their general physics achievement, the physics lesson performance in high school and the test scores. In addition, the success of students in the physics lab was influenced by the students' physics lab attitudes and non-cognitive variables such as anxiety and self-efficacy beliefs. Therefore, the main purpose of this study is to indicate structural equation modeling on self-efficacy, physics lab anxiety and attitudes. In this research, 513 university students participated, and three scales were used to data collection including Self-efficacy Scale, Physics Lab Anxiety Scale (PLAS), and Physics Lab Attitudes Scale. In correlation analysis, physics lab anxiety was found negatively related to physics lab attitudes and self-efficacy. According to path analysis results, physics lab attitudes were predicted positively by self-efficacy. Furthermore, self-efficacy and physics lab attitudes were predicted by physics lab anxiety in a negative way. The study revealed that high self-efficacy and positive attitudes toward physics decreases physics lab anxiety. The findings were discussed using the literature in this field.
\end{abstract}

Keywords: Physics lab anxiety, physics lab attitudes, self-efficacy, structural equation model

\section{Introduction}

Physics is a fundamental discipline of natural sciences and it has important roles in engineering, chemistry and mathematics. However, many students are struggling in physics (Byun et al., 2008; Raw, 1999). Therefore, some students change their branches when they achieve bad scores in physics course (Tuminaro \& Redish, 2004). In addition, physics are supported by lab studies to consolidate and understand physics concepts in high schools and universities. In this context, Millar (2004) pointed out the importance of practical work to help students make a connection between concepts and their observable properties. Therefore, lab activities have an important and central role in the science education (Hofstein \& Lunetta, 2004; Lunetta, 1998). In this sense, lab studies have the potential to develop meaningful learning, conceptual understanding and understanding of the nature of science (Taitelbaum et al., 2008). Further, lab studies are also useful for high level learning skills such as observation, experiment planning, asking questions, hypothesizing and analyzing experimental results (Bybee, 2000; Hofstein et al., 2004).

The most important active learning environments in physics education are physics labs. Physics lab is private classrooms where physics concepts are taught. Students' achievements in physics lab depend on

\footnotetext{
${ }^{1}$ Prof. Dr., Departmen of Science Education, Sakarya University, Turkey, kurbaoglu@sakarya.edu.tr, ORCID: 0000-00025340-0855

${ }^{2}$ Assist. Dr., Departmen of Mathematics Education, Sakarya University, Turkey, mtakunyaci@sakarya.edu.tr, ORCID: 00000003-1065-975X
} 
general physics achievements, high school physics course performance, and test scores. In addition, students' achievement in physics lab was influenced from positive or negative attitudes of students toward physics lab. Also, non-cognitive variables such as anxiety and self-efficacy beliefs play a key role in general physics achievement. Anxiety is one of the most common psychological disorders that cause to increase their fears of individuals about the future (Schmidt et al., 2008). The anxiety was defined by different fields of science. Mallow (1986) defined the science anxiety as disgust or fear of science concepts, scientists, and science-related activities. Seligman Walkman et al. (2001) described the science anxiety as the tension that hinders the use of scientific equipment in academic subjects and in the various stages of daily life. In addition, Oludipe and Awokoy (2010) defined science anxiety as a disturbing situation in responding to situations perceiving threatening self-respect and include scientific studies. Also, Mallow and Greenburg (1982) defined science anxiety as a condition and a fear of science that adversely affected students' science learning. They also stated that science anxiety caused students to fear being enrolled in science courses and, as a result, prevented many of them from entering and succeeding in science (Raymond, 2003; Udo et al., 2004). Students who have science anxiety think that they would not be able to solve science problems or be successful in science exams would constitute their science concerns (Mallow \& Greenburg, 1982). Regarding this issue, Mahajan and Singh (2001) stated that the presence of anxiety affects students' understanding related to the subject. Thus, anxiety is a factor that reduces the performance in the physics lab course. Anxiety feeling causes loss of helplessness, tension, panic, fear, inability to cope and concentration problem (Seligman Walkman et al., 2001). In addition, some studies showed that there was a negative relationship between anxiety and students' success because of anxiety in education (Berdonosov et al., 1999; Black \& Deci, 2000; Eddy, 2000).

Physics lab anxiety leading a broad spectrum of psychological, cognitive, and behavioral problems and is affected by many variables. Attitude is one of these variables. According to Brandwein et al. (1958), attitude "shows the emotional aspect of the individual against the subject" (Freedman, 1997). Attitude has been defined by Eagly and Chaiken (1993) as psychological tendency which measures the degree of liking or disliking a particular case and has been considered playing an important role on development of anxiety mostly every field of education (Osborne et al., 2003) and positive and negative attitudes of students impact the outcomes of science courses in high school and university (Cheung, 2009). Schibeci (1983) exuded that scientific attitude has a predominant cognitive orientation, whereas attitude toward science is predominantly affective (Freedman, 1997). In this context, science attitude was defined by Koballa and Crawley (1985) as liking or disliking the science.

Increasing students' positive attitudes towards physics laboratory concerns is very important in terms of two main reasons. The first reason is the link between attitudes and academic achievement (Bennett et al., 2001; Cheung, 2009; Freedman, 1997; Salta \& Tzougraki, 2004; Weinburgh, 1995) and the second one is estimation of behaviors by attitudes (Glasman \& Albarracín, 2006). Another construct related to physics lab anxiety is self-efficacy beliefs. The self-efficacy has become a widely studied subject in education, psychology and organizational science (Scherbaum et al., 2006). Firstly, it was observed that self-efficacy in social learning theory of Bandura (1977). According to the social learning theory, as human behavior and motivation are regulated by intense common sense and as a result self-efficacy is stated as the primary factor regulating human behavior (Luszczynska et al., 2005). Bandura $(1977,1986)$ argued that self-efficacy influences, and also is influenced by, thought patterns, affective arousal, and choice behavior as well as task performance. According to Bandura (1997) self-efficacy is the self-judgment about the capacity of the 
individual to organize and perform the activities that are necessary to show a certain performance. In addition, Luszczynska, et al. (2005) defined self-efficacy as people's belief in their ability to perform in a particular situation to achieve a desired result. According to Ylldırım and İlhan (2010), the concept of selfefficacy includes elements such as planning an action, being aware of the necessary skills and organizing, and the level of motivation as a result of reviewing the gains to be obtained through difficulties (Uysal, 2013). Research has shown that students' ability to be successful in tasks, lectures, events, or their belief in self-efficacy, has a strong impact on science-related activity choices and achievements (Bandura, 1997; Britner \& Pajares, 2001; Dalgety et al., 2003; Zeldin \& Pajares, 2000). Students who have a strong belief that they can succeed in tasks and activities would be more likely to select such tasks and activities and work hard to complete them successfully whereas students who do not have self-efficacy beliefs would avoid them if they can and would put forth minimal effort if they cannot (Britner \& Pajares, 2006; Crippen \& Earl, 2007). Although the studies are generally focused on science anxiety (Laukenmann et al., 2003; Eddy, 2000), the concern of the physics laboratory in literature has received little attention. Therefore, this research aims to examine the relationships between self-efficacy, physics lab anxiety and attitudes.

\section{Method}

The study is a research based on descriptive-relational design using surveys. In this study, the relationships between self-efficacy, physics lab anxiety and attitudes were examined by using structural equality model.

\section{Participants}

Five hundred thirteen university students ( 263 male, 250 female) who were enrolled in physics laboratory course from four different state universities, participated in current study in Turkey. The age range of the students ranged from 18 to 24 , and the average age was 21 years.

\section{Research Instruments}

\section{The Physics Lab Anxiety Scale}

The Physics Lab Anxiety Scale (P-LAS) was developed by Kurbanoglu \& Akın (2012a) and revised by Kurbanoglu \& Takunyacı (2017). This scale is an 18-item (e.g., entering the physics lab) self-reports measurement. The scale is a 5 -point Likert scale $(1=$ never makes me anxious, $5=$ always makes me anxious). The Cronbach's alpha of the scale was .94.

\section{The Physics Lab Attitudes Scale}

The Physics Lab Attitudes Scale was developed by Kurbanoğlu \& Akın (2012b, 2014). This scale contains 13 items (e.g., it is more interesting to learn physics terms by doing experiments). The scale is a 5-point Likert scale. The Cronbach's alpha of the scale was .94.

\section{Self-efficacy Scale}

Turkish adaptation of this scale had been done by Büyüköztürk et al. (2004). The Self-efficacy subscale consists of eight items and each item was rated on a 7-point Likert scale. The Cronbach's alpha of the scale was .86 . 


\section{Statistical Analysis}

The data obtained from 513 students were statistically analyzed. In this research, Pearson correlation coefficient was used to analyze relations between self-efficacy, physics lab attitudes, and physics lab anxiety. Then structural equation modeling (SEM) was used to reveal predictive relationship among variables. Analyses were carried out with SPSS 21 and LISREL 8.54.

\section{Findings}

Table 1 shows the means, descriptive statistics, internal consistency coefficients, and inter-correlations of the variables used.

\section{Table 1}

Descriptive Statistics, Internal Consistency Coefficients, and Inter-Correlations

\begin{tabular}{llll}
\hline Variables & 1 & 2 & 3 \\
\hline 1. Physics lab attitudes & 1.00 & & \\
2. Self-efficacy related to learn. & $.30^{* *}$ & 1.00 & \\
3. Physics lab anxiety & $-.42^{* *}$ & $-.32^{* *}$ & 1.00 \\
\hline Mean & 56.57 & 40.39 & 68.22 \\
Standard deviation & 8.81 & 7.95 & 18.30 \\
Internal consistency coefficients & .92 & .81 & .90 \\
\hline
\end{tabular}

${ }^{* *} p<.01$

When Table 1 is examined, it is seen that there are significant correlations between physics lab attitudes, self-efficacy related to learning and performance, and physics lab anxiety. Physics lab anxiety is negatively related to physics lab attitudes $(r=-.42)$ and self-efficacy on learning and performance $(r=-.32)$. On the other hand physics lab attitudes were found positively associated with self-efficacy on learning and performance $(r=.30)$.

\section{Structural Equation Modeling}

Figure 1 presents the results of SEM analysis, using maximum likelihood estimations. The analysis showed that the model is saturated (i.e., there are no unused degrees of freedom). Consequently, the model fitted well $(\chi 2=3.23$, GFI=.95, AGFI=.96, CFI=.97, NFI=.98, RFI=.94, IFI=.95, and RMSEA =.032). 


\section{Figure 1}

Structural Equation Model

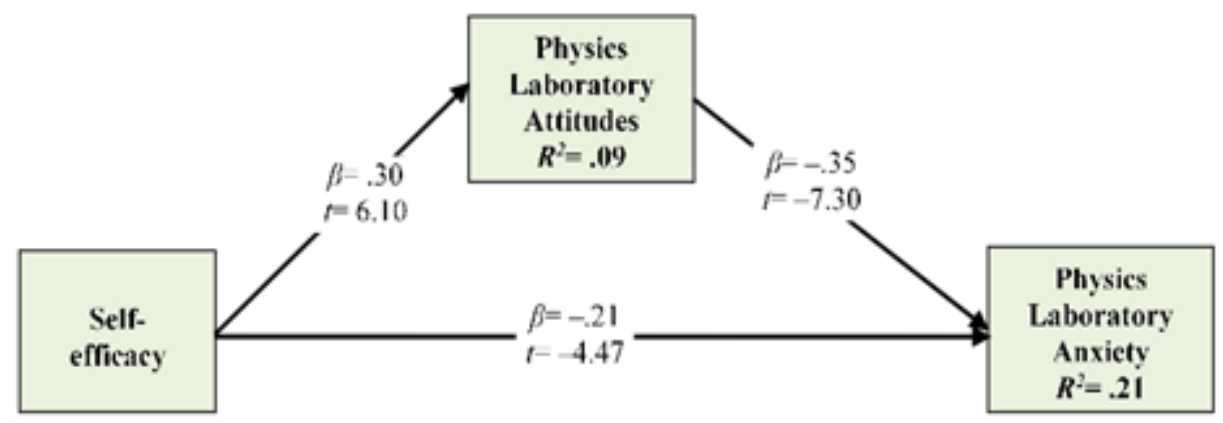

The standardized coefficients in Figure 1 clearly showed that self-efficacy predicted physics lab anxiety in a negative way (-.21). Also, self-efficacy has a direct and positive effect on physics lab attitudes (.30) which in turn affects physics lab anxiety. Finally, physics lab anxiety was explained negatively by physics lab attitudes (-.35).

\section{Discussion}

The purpose of this study was to investigate the relationships between physics laboratory anxiety, physics laboratory attitudes, and self-efficacy. Results revealed that there were significant relationships between these variables. Moreover, the goodness of fit indexes indicated that correlations among measures were explained by the model and that its formulation was psychometrically acceptable (Hu \& Bentler, 1999).

As predicted, the model showed that physics laboratory anxiety was explained by self-efficacy negatively. This result is consistent with previous studies (Britner, 2008; Britner \& Pajares, 2006; Eddy, 2000; Kurbanoglu \& Akın, 2010; Usher \& Pajares, 2006) demonstrating anxiety and self-efficacy are inversely related constructs and with Bandura's (1986) social cognitive theory stating anxiety has a negative effect on self-efficacy. Moreover, this finding is also consistent with Bandura's (1997) assertion suggesting efficacy beliefs play a central role in regulating anxiety. In addition, the negative relationship between self-efficacy and physics laboratory anxiety was supported by Hackett's (1995) suggestion that "it is possible, that lowered anxiety not only enhances self-efficacy directly but also facilitates successful performance attempts in occupationally related areas." Therefore, a student who feels anxious about physics laboratory can hardly feel capable of doing physics laboratory activities and so self-efficacy could be a negative predictor of physics laboratory anxiety.

Secondly, as expected, and consistent with previous research findings (Kurbanoglu \& Akın, 2010, 2012b, Liu et al., 2006; Smist \& Owen, 1994) path analysis revealed that physics laboratory attitudes were predicted positively by self-efficacy. In addition, self-efficacy reduced indirectly physics laboratory anxiety through physics laboratory attitudes. In other words, physics laboratory attitudes played a mediator role in the link self-efficacy and physics laboratory anxiety. Students' physics laboratory attitudes are important factors highly associated with physics laboratory success and motivation. Students 
who have more positive attitudes towards physics laboratory are more likely to exert their efforts and have the desire to be involved in the learning tasks.

Thirdly, as anticipated, results demonstrated that physics laboratory anxiety was negatively predicted by physics laboratory attitudes. This finding is consistent with the results of earlier investigations indicating students who have higher levels of positive attitudes about a course have also low level of anxiety in terms of related topic (Keeves \& Morgenstern, 1992; Kurbanoglu \& Akın, 2010; Kurbanoglu, Akın, \& Takunyac1, 2009; Meece et al., 1990). In general, there is a widely accepted agreement that attitudes are deeply associated with expectations of success and the subjective value of the task and would impact on students' level of anxiety (Child et al., 1997). Consequently, physics laboratory anxiety is promoted by negative attitudes towards physics laboratory, while it is decreased by positive ones.

This study has several implications for future research. Firstly, further research investigating the relationships between physics laboratory anxiety, physics laboratory attitudes, self-efficacy, and other psychological constructs need to reinforce the findings of this study. Second, we urge researchers to use quantitative methodology to complement findings from qualitative perspectives. The present study also has several indirect implications for physics educators. First, reducing or controlling anxiety in physics laboratory courses potentially may enhance learning and quality of physics laboratory activities. Helping students to control anxiety related to physics laboratory activities can increase the development of positive self-efficacy beliefs and ultimately lead to more positive attitudes toward physics laboratory. Students who approach a physics laboratory activity with worry likely lack confidence in their science skills. Furthermore, these negative feelings can induce additional stress that cause the inadequate performance feared (Britner \& Pajares, 2006).

Since students' efficacy beliefs develop based on authentic accomplishments (Bandura, 1997), another implication for educators is to create physics laboratory experiences in which students can improve their sense of self-efficacy. Thus, if students have low sense of self-efficacy, more instructional time in performing physics experiments must be spent. So that, students will perceive themselves as more successful persons and their sense of efficacy will be enhanced accordingly. Finally, inquiry-based instructional strategies in which students are mentally and physically active can be administrated that help students become more self-aware of their improvement (Uzuntiryaki \& Capa Aydin, 2009).

Although the results of the present study have implications for interventions that could decrease students' physics laboratory anxiety and increase their self-efficacy, some limitations of the current study should be mentioned. First, because participants of the present research are consisted of university students, replication of this study for targeting other student populations should be made to generate a more solid relationship among constructs examined in this study. Second, as correlational statistics were utilized, no definitive statements can be made about causality. Third, the self-report instruments used in this study may not appropriately capture the participants' perceptions and feelings. Finally, since the proportions of variance explained were low, it is difficult to make any firm conclusions about the findings.

In sum, this study demonstrates that self-efficacy affects the physics laboratory anxiety and physics laboratory attitudes, directly. Students who have low levels of self-efficacy are more likely to vulnerability to physics laboratory anxiety and negative physics laboratory attitudes. So, the current findings increase our understanding of the relationships between self-efficacy, physics laboratory anxiety, and physics laboratory attitudes. 


\section{References}

Bandura, A. (1977). Self-efficacy: Toward a unifying theory of behavioral change. Psychological Review, $84(2), 191-215$.

Bandura, A. (1986). Social foundations of thought and action: A social cognitive theory. Englewood Cliffs, NJ: Prentice-Hall.

Bandura, A. (1997). Self-efficacy: The exercise of control. New York: Freeman.

Bennett, J., Rollnick, M., Green, G., \& White, M. (2001). The development and use of an instrument to assess students' attitude to the study of chemistry. International Journal of Science Education, 23(8), 833-845.

Berdonosov, S. S., Kurzmenko, N. E., \& Kharisov, B. I. (1999). Experience in chemical education in Russia: How to attract the young generation to chemistry under conditions of "chemophobia" Journal of Chemical Education, 76(8), 1086-1088.

Black, A. E., \& Deci, E. L. (2000). The effects of instructors' autonomy support and students' autonomous motivation on learning organic chemistry: A self-determination theory Perspective, Science Education, 84,740-756.

Brandwein, P. F., Watson, F. G., \& Blackwood, P. E. (1958). Teaching high school science: A book of methods. New York, NY: Barcourt, Brace \& World, Inc.

Britner, S. L. (2008). Motivation in high school science students: A comparison of gender differences in life, physical, and earth science classes. Journal of Research in Science Teaching, 45(8), 955-970.

Britner, S. L., \& Pajares, F. (2001). Self-efficacy beliefs, motivation, race, and gender in middle school science. Journal of Women and Minorities in Science and Engineering, 7, 271-285.

Britner, S. L., \& Pajares, F. (2006). Sources of science self-efficacy beliefs of middle school students. Journal of Research in Science Teaching, 43(5), 485-499.

Büyüköztürk, Ş., Akgün, Ö., Özkahveci, Ö., \& Demirel, F. (2004). The validity and reliability study of the Turkish version of the Motivated Strategies for Learning Questionnaire. Educational Science: Theory E Practice, 4(2), 207-239.

Bybee, R. (2000). Teaching science as inquiry. In J. Minstrel \& E. H. Van Zee (Eds.), Inquiring into inquiry learning and teaching in science. Washington: AAAS.

Byun, T., Ha, S., \& Lee, G. (2008). Identifying student difficulty in problem solving process via of the house model. Proceedings of the Physics Education Research Conference, 1064, 87-90. Edmonton, Alberta: AIP.

Cheung, D. (2009). Students' attitudes toward chemistry lessons: The interaction effect between grade level and gender. Research in Science Education, 39, 75-91.

Child, D. A., Duffy, T. M., Kirkley, S., \& Hubbard, L. (1997). Issues in adopting a laser disk based science curriculum. Journal of Science Education and Technology, 6(3), 161-171.

Crippen, K. J., \& Earl, B. L. (2007). The impact of web-based worked examples and self explanation on performance, problem solving, and self-efficacy. Computers $\mathcal{E}$ Education, 49(3), 809-821. 
Eagly, A. H., \& Chaiken, S. (1993). The psychology of attitudes. Fort Worth, FL: Harcourt Brace \& Company.

Eddy, R. M. (2000). Chemophobia in the college classroom: Extent, sources, and student characteristics, Journal of Chemical Education, 77, 514-517.

Freedman, M. P. (1997). Relationship among laboratory instruction, attitude toward science, and achievement in science knowledge. Journal of Research in Science Teaching, 34(4), 343-357.

Dalgety, J., Coll, R. K., \& Jones, A. (2003). Development of chemistry attitudes and experiences questionnaire (CAEQ). Journal of Research in Science Teaching, 40(7), 649-668.

Glasman, L. R., \& Albarracin, D. (2006). Forming attitudes that predict future behavior: A meta-analysis of the attitude-behavior relation. Psychological Bulletin, 132, 778-822.

Hackett, G. (1995). Self-efficacy in career choice and development. In: A. Bandura, Editor, Self-efficacy in changing societies, Cambridge University Press, New York, pp. 232-258.

Hofstein, A., \& Lunetta, V. N. (2004). The laboratory in science education: foundations for the twenty-first century. Science Education, 88, 28-54.

Hofstein, A., Shore, R., \& Kipnis, M. (2004). Providing high school chemistry students with opportunities to develop learning skills in an inquiry-type laboratory: a case study. International Journal of Science Education, 26, 47-62.

Hu, L. T., \& Bentler, P. M. (1999). Cutoff criteria for fit indexes in covariance structural analysis: Conventional criteria versus new alternatives. Structural Equation Modeling, 6, 1-55.

Keeves, J. P., \& Morgenstern, C. (1992). Attitudes toward science: Measures and effects. In J.P. Keeves (Ed.) The IEA Study of Science III: Changes in science Education and Achievement: 1970-1984 (pp. 122140). New York: Pergamon.

Koballa, T. R., \& Crawley, F. E. (1985). The influence of attitude on science teaching and learning. School Science and Mathematics, 85(3), 222-232.

Kurbanoglu, N. İ., Akın, A., \& Takunyacı, M. (2009, July). The relationships between chemistry laboratory anxiety and chemistry attitudes. Paper presented at the $30^{\text {th }}$ International Conference of the Stress and Anxiety Research Society (STAR), July, 16-18, Budapest, Hungary.

Kurbanoglu, N. İ., \& Akın, A. (2010). The relationships between university students' chemistry laboratory anxiety, attitudes, and self-efficacy beliefs. Australian Journal of Teacher Education, 35(8), 48-59.

Kurbanoglu, N. İ., \& Akın, A. (2012). The relationships between university students' organic chemistry anxiety, chemistry attitudes, and self-efficacy: a structural equation model. Journal of Baltic Science Education, 11(4), 347-356.

Kurbanoglu, N. İ., \& Akın, A. (2012a). Development and validation of a scale to measure physics laboratory anxiety level of university students. Paper presented at the International Counseling and Education Conference, İstanbul, Turkey.

Kurbanoglu, N. İ., \& Akın, A. (2012b). Development and validation of a scale to measure physics laboratory attitude level of university students. Paper presented at the International Counseling and Education Conference, İstanbul, Turkey. 
Kurbanoglu, N. İ., \& Akın, A. (2014). Development and validation of a scale to measure physics laboratory attitude level of university students. Physics Education (IAPT), 30(1), 1-6.

Kurbanoğlu, N. İ., \& Takunyacı, M. (2017). Development and Evaluation of an Instrument Measuring Anxiety toward Physics Laboratory Classes among University Students. Journal of Baltic Science Education, 16(4).

Laukenmann. M., Bleicher, M., Fu, S., Glaser-Zikuda, M., Mayring, P., \& Von Rhöneck, C. (2003). An investigation of the influence of emotional factors on leaning in physics instruction. International Journal of Science Education, 25(4), 489-507.

Liu, M., Hsieh, P., Cho, Y., \& Schallert, D. (2006). Middle school students' self-efficacy, attitudes, and achievement in a computer-enhanced problem-based learning environment. Journal of Interactive Learning Research, 17(3), 223-242.

Lunetta, V. N. (1998). The school science laboratory: Historical perspectives and context for contemporary teaching. In B. Fraser \& K. G. Tobin. (Eds.), International handbook of science education (249-262). Dodrecht, The Netherlands: Kluwer.

Luszczynska, A., Gutiérrez-Dona, B., \& Schwarzer, R. (2005). General self-efficacy in various domains of human functioning: Evidence from five countries, International Journal of Psychology, 40(2), 80-89.

Mahajan, D. S., \& Singh, G. S. (2001). Phobia towards organic chemistry in year one students at the University of Botswana. Lonaka: Bulletin of the Center for Academic Development University of Botswana, 3, 22.

Mallow, J. (1986). Science Anxiety. Clearwater, FL: H \& H Publication.

Mallow, J.V., \& Greenburg, S.L. (1982). Science anxiety: Causes and remedies. Journal of College Science Teaching, 11, 356-358.

Meece, J. L., Wigfield, A., \& Eccles, J. S. (1990). Predictors of math anxiety and its influence on young adolescents' course enrollment intentions and performance in mathematics. Journal of Educational Psychology, 82, 60-70.

Millar, R. (2004). High school science laboratory: Role and vision. National Academy of Science, Washington, DC 3-4 June.

Oludipe, D., \& Awokoy, J. O. (2010). Effect of cooperative learning teaching strategy on the reduction of students' anxiety for learning chemistry. Journal of Turkish Science Education, 7(1), 30-36.

Osborne, J., Simon, S., \& Collins, S. (2003). Attitudes towards science: A review of the literature and its implications. International Journal of Science Education, 25(9), 1049-1079.

Raw, A. J. (1999). Developing a-level physics students' mathematical skills a way forward? Physics Education, 34(5), 306-310.

Raymond, L. (2003). Globalization, the knowledge economy, and competitiveness: a business intelligence framework for the development SMES, Journal of American Academy of Business, 3(1/2), 260-76.

Salta, K., \& Tzougraki, C. (2004). Attitudes toward chemistry among 11th grade students in high schools in Greece. Science Education, 88, 535- 547. 
Seligman Walkman, M. E. P., Walker, E. F., \& Rossenhan, D. L. (2001). Abnormal Psychology (4thedition). N.Y.:W.W. Norton \& company, Inc.

Scherbaum, C., Cohen-Charash, Y., \& Kern, M. (2006). Measuring General Self-Efficacy: A Comparison of Three Measures Using Item Response Theory. Educational and Psychological Measurement, 66, 10471063.

Schibeci, R. A. (1983). Selecting appropriate attitudinal objectives for school science, Science Education, 67(5), 595-603.

Schmidt, N. B., Mitchell, M. A., \& Richey, J. A. (2008). Anxiety sensitivity as an incremental predictor of later anxiety symptoms and syndromes. Comprehensive Psychiatry, 49, 407-412.

Smist, J. M., \& Owen, S. V. (1994, April). Explaining science self-efficacy. Paper presented at the annual meeting of the American Educational Research Association. New Orleans, LA.

Taitelbaum, D., Mamlok-Naaman, R., Carmeli, M., \& Hofstein, A. (2008). Evidence for teachers' change while Participating in a continuous professional development programme and implementing the inquiry approach in the chemistry laboratory. International Journal of Science Education, 30(5), 593617.

Tuminaro, J., \& Redish, E. (2004). Understanding students' poor performance on mathematical problem solving in physics. Paper presented at the Physics Education Research Conference.

Udo, M. K., Ramsey, G. P., \& Mallow, J. V. (2004). Science anxiety and gender in students taking general education science courses. Journal of Science Education and Technology, 13(4), 435-446.

Usher, E. L., \& Pajares, F. (2006). Sources of academic and self-regulatory efficacy beliefs of entering middle school students. Contemporary Educational Psychology, 31, 125-141.

Uysal, İ. (2013). Akademisyenlerin Genel Öz-Yeterlik İnançları: AİBÜ Eğitim Fakültesi Örneği. Trakya Üniversitesi Ĕ̆itim Fakültesi Dergisi, 3(2).

Uzuntiryaki, E., \& Capa Aydin, Y. (2009). Development and validation of Chemistry Self-efficacy Scale for college students. Research in Science Education, 39(4), 539-551.

Weinburgh, M. (1995). Gender differences in student attitudes toward science: A meta-analysis of the literature from 1970 to 1991. Journal of Research in Science Teaching, 32, 387-398.

Yıldırım, F. \& İlhan, İ.Ö. (2010). Genel Özyeterlilik Ölçeği Türkçe Formunun geçerlilik ve güvenilirlik çalışması. Türk Psikiyatri Dergisi, 21(4), 301-8.

Zeldin, A. L., \& Pajares, F. (2000). Against the odds: Self-efficacy beliefs of women in mathematical, scientific, and technological careers. American Educational Research Journal, 37, 215-246. 